\title{
Aralia cordata Protects Against Amyloid $\beta$ Protein (25-35)-Induced Neurotoxicity in Cultured Neurons and Has Antidementia Activities in Mice
}

\author{
Soon Ock Cho ${ }^{1, \uparrow}$, Ju Yeon Ban ${ }^{2, \uparrow}$, Joo Youn Kim ${ }^{1}$, Ha Yeon Jeong ${ }^{1}$, Ik Soo Lee ${ }^{3}$, Kyung-Sik Song ${ }^{4}$, \\ KiHwan $\mathrm{Bae}^{3, * a}$, and Yeon Hee Seong ${ }^{1, * b}$ \\ ${ }^{I}$ College of Veterinary Medicine, Chungbuk National University, Cheongju, Chungbuk, 361-763, Korea \\ ${ }^{2}$ School of Dentistry, Dankook University, Cheonan, Chungnam, 330-714, Korea \\ ${ }^{3}$ College of Pharmacy, Chungnam National University, Taejon, 305-764, Korea \\ ${ }^{4}$ College of Agriculture and Life-Sciences, Kyungpook National University, Daegu, 702-701, Korea
}

Received October 4, 2008; Accepted June 26, 2009

\begin{abstract}
The present study investigated an ethanol extract of the aerial part of Aralia cordata Thunb. (Araliaceae) for possible neuroprotective effects on neurotoxicity induced by amyloid $\beta$ $(\mathrm{A} \beta)$ protein $(25-35)$ in cultured rat cortical neurons and antidementia activity in mice. Exposure of cultured cortical neurons to $10 \mu \mathrm{M} \mathrm{A} \beta(25-35)$ for $36 \mathrm{~h}$ induced neuronal apoptotic death. At $1-10 \mu \mathrm{g} / \mathrm{ml}$, A. cordata inhibited neuronal death, elevation of intracellular calcium $\left(\left[\mathrm{Ca}^{2+}\right]_{\mathrm{i}}\right)$, glutamate release into the medium, and generation of reactive oxygen species (ROS) induced by $\mathrm{A} \beta(25-35)$ in primary cultures of rat cortical neurons. Memory loss induced by intracerebroventricular injection of ICR mice with $15 \mathrm{nmol} \mathrm{A} \beta(25-35)$ was inhibited by chronic treatment with A. cordata (50 and $100 \mathrm{mg} / \mathrm{kg}$, p.o. for 7 days) as measured by a passive avoidance test, and corresponding reductions were observed in brain cholinesterase activity and neuronal death measured histologically in the hippocampal region. Oleanolic acid isolated from A. cordata also inhibited neuronal death, elevation of $\left[\mathrm{Ca}^{2+}\right]_{\text {i, }}$ glutamate release, and generation of ROS induced by $\mathrm{A} \beta(25-35)$ in cultured rat cortical neurons, suggesting that the neuroprotective effect of $A$. cordata may be, at least in part, attributable to this compound. From these results, we suggest that the antidementia effect of $A$. cordata is due to its neuroprotective effect against $\mathrm{A} \beta(25-35)$-induced neurotoxicity and that $A$. cordata may have a therapeutic role in preventing the progression of Alzheimer's disease.
\end{abstract}

Keywords: Aralia cordata, oleanolic acid, amyloid $\beta$ protein, cultured neuronal death, memory impairment

\section{Introduction}

Alzheimer's disease (AD) is a neurodegenerative disorder characterized clinically by cognitive impairment and pathologically by the appearance of senile plaques and neurofibrillary tangles (1). Amyloid $\beta$ protein $(\mathrm{A} \beta)$, a 39- to 43 -amino-acid peptide fragment derived from amyloid precursor protein, is thought to

\footnotetext{
These authors equally contributed to this work. Corresponding authors.

*abaekh@cnu.ac.kr, *bvepharm@chungbuk.ac.kr Published online in J-STAGE doi: $10.1254 /$ jphs.08271FP
}

be closely related to the pathogenesis of $\mathrm{AD}$ as the major component of the senile plaques that characterize this disease (2). Although the precise mechanism of $\mathrm{A} \beta$ induced cell death is not well understood, $\mathrm{A} \beta$ neurotoxicity has been speculated to be due to various factors, including oxidative stress, excessive increases in intracellular $\mathrm{Ca}^{2+}\left(\left[\mathrm{Ca}^{2+}\right]_{\mathrm{i}}\right)$, and glutamate accumulation, and induction of neurotoxic cascades $(3-5)$.

An experimental model that mimics the progression of $\mathrm{AD}$ was developed using an intracerebroventricular (i.c.v.) injection of $A \beta$ in mice (6). A continuous infusion of full-length $\mathrm{A} \beta, \mathrm{A} \beta(1-40)$, into the cerebral ventricle in rats resulted in learning and memory deficits 
that were accompanied by a reduction of choline acetyltransferase activity, suggesting that accumulation of $\mathrm{A} \beta$ disrupted cholinergic activity and caused the cognitive impairments of $\mathrm{AD}$ (7). Oxidative stresses are also involved in the mechanism of $\mathrm{A} \beta$-induced neurotoxicity and $\mathrm{AD}$ pathogenesis $(8,9) . \mathrm{A} \beta$ has been reported to produce hydrogen peroxide and lipid peroxide in neurons and superoxide and proinflammatory cytokines in astrocytes and microglial cells $(10,11)$. Antioxidants such as $\alpha$-tocopherol protect against cytotoxicity induced by $\mathrm{A} \beta$ in vitro as well as against learning and memory deficits in vivo (12). Also, $\alpha$-tocopherol and anti-inflammatory agents such as indomethacin reportedly slow the progression of $\mathrm{AD}(13,14) . \mathrm{A} \beta(25-35)$, the core toxic fragment of $\mathrm{A} \beta(1-40)$, produces similar neurodegenerative properties as $\mathrm{A} \beta(1-40)$, including oxidative damage, inflammatory responses, and memory impairment $(15,16)$.

Aralia species belong to the family Araliaceae and have long been recognized in China, Japan, and Korea as therapeutic herbs with antinociceptive, antidiabetic, antioxidant, and anti-inflammatory activities. The root of Aralia cordata Thunb. has been used as a traditional Chinese medicine for rheumatism, lumbago, and lameness (17). It exhibits pharmacological activities such as analgesia, hypothermia, and prolongation of pentobarbital-induced anesthesia (18). Diterpenes have been elucidated as analgesic and anti-inflammatory agents of this plant root $(18,19)$. In addition to diterpenes, polyacetylenes, a lipid glycerol, and sterols having cyclooxygenase (COX) inhibitory activity have been isolated from the root (20); and diterpenes, triterpenes, and a saponin have been isolated as COX-1 and COX-2 inhibitors from the aerial part of this plant (21). Since reactive oxygen species (ROS) and inflammation are part of the complex series of pathophysiological events that contribute to neurodegenerative diseases such as $\mathrm{AD}$ and stroke $(22,23)$, free radical scavengers and anti-inflammatory agents have attracted considerable attention as potential neuroprotective agents. We hypothesized that the aerial part of $A$. cordata might protect neurons against neurodegenerative diseases such as $\mathrm{AD}$ and ischemia on the basis of its antioxidant and antiinflammatory activities. The aim of our study was to determine whether $A$. cordata has a protective effect against $\mathrm{A} \beta(25-35)$-induced memory deficits in mice and $\mathrm{A} \beta(25-35)$-induced neuronal damage in cultured rat cortical neurons. In addition, we identified oleanolic acid as an active component contributing to the neuroprotective effect of $A$. Cordata against A $\beta(25-35)$ induced neurotoxicity.

\section{Materials and Methods}

\section{Plant material, preparation, and identification}

The aerial parts of A.cordata were collected in Daejeon, Korea and identified by one of the authors (Dr. KiHwan Bae). A voucher specimen (CNU 1499) has been deposited in the herbarium at the College of Pharmacy, Chungnam National University, Daejeon, Korea. The dried aerial parts of $A$. cordata $(4 \mathrm{~kg})$ were extracted 3 times with ethanol at room temperature for 3 days, filtered, and concentrated to yield an ethanol extract ( $300 \mathrm{~g}$, yield: $7.5 \%)$, which was then stored at $-20^{\circ} \mathrm{C}$ until required. A. cordata was standardized based on its oleanolic acid contents. Oleanolic acid was determined using reverse-phase high-performance liquid chromatography (HPLC; Shimadzu, Kyoto) equipped with a UV detector. Separation was carried out using a YMC-pack pro $\mathrm{C}_{18}$ column $(5 \mu \mathrm{m}, 10 \times 250 \mathrm{~mm}$; Shisheido, Tokyo) at $30^{\circ} \mathrm{C}$ with a linear gradient of acetonitrile:water $(20: 80, \mathrm{v} / \mathrm{v})$ and acetonitrile:water $(30: 70, \mathrm{v} / \mathrm{v})$ as the mobile phase at a flow rate of $1.5 \mathrm{ml} / \mathrm{min}$. The detector wavelength was set at $210 \mathrm{~nm}$. Oleanolic acid was found in the aerial parts of $A$. cordata at a mean level of $2.20 \pm 0.08 \%(n=3$, Fig. 1).

The ethanol extract of $A$. cordata was suspended in $\mathrm{H}_{2} \mathrm{O}(2 \mathrm{~L})$ and then partitioned successively with hexane $(2 \mathrm{~L} \times 3)$, ethyl acetate $(2 \mathrm{~L} \times 3)$, and butanol $(2 \mathrm{~L} \times 3)$ for activity-guided purification. Since the hexanesoluble fraction exhibited considerable activity, this fraction was investigated extensively. The hexanesoluble fraction $(85 \mathrm{~g})$ was chromatographed on a silica gel column $(30 \times 10.0 \mathrm{~cm})$ and eluted with a gradient of hexane-acetone $(100: 1 \rightarrow 1: 2)$ to produce 4 fractions. Repeated silica gel column chromatography $(30 \times 5.0$ $\mathrm{cm})$ of fraction 4 using hexane-acetone $(4: 1)$ gave compound $1(25 \mathrm{mg})$.

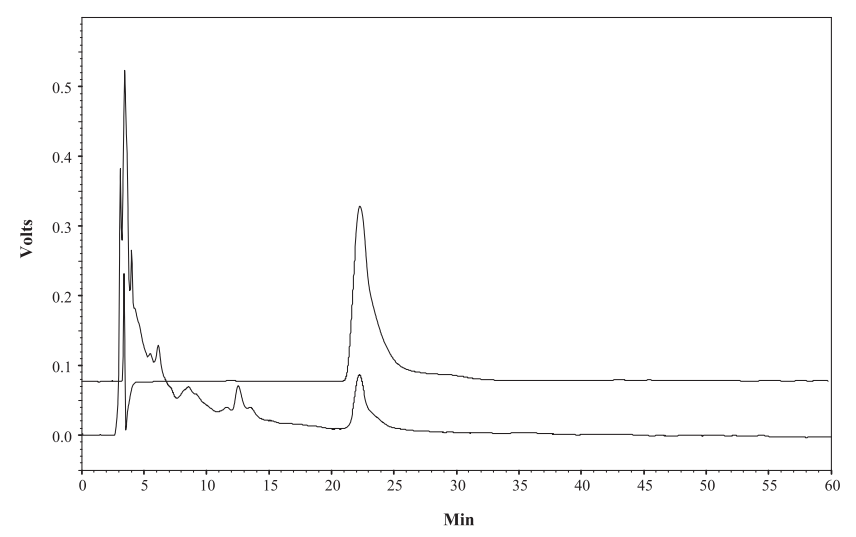

Fig. 1. Representative HPLC chromatogram of standard oleanolic acid (top trace) and the ethanol extract of $A$. cordata (bottom trace). Oleanolic acid was detected at around $22 \mathrm{~min}$ in this system. 
Properties of Compound 1 (oleanolic acid):

white powder

mp: $196^{\circ} \mathrm{C}-198^{\circ} \mathrm{C}$.

IR (KBr) $v_{\max } \mathrm{cm}^{-1}: 3430(\mathrm{OH}), 1705(\mathrm{COOH})$.

1H-NMR (300 MHz, $\left.\mathrm{CDCl}_{3}\right) \delta$ (ppm): 0.74, 0.79, $0.90,0.92,0.93,0.99$, and 1.12 (each $3 \mathrm{H}, \mathrm{s}), 3.22$

$(1 \mathrm{H}, \mathrm{dd}, J=4.0,9.5 \mathrm{~Hz}, \mathrm{H}-3), 5.28(1 \mathrm{H}, \mathrm{m}, \mathrm{H}-12)$.

${ }^{13} \mathrm{C}-\mathrm{NMR}\left(75 \mathrm{MHz}, \mathrm{CDCl}_{3}\right.$ ) (ppm): 38.9 (C-1), 28.4

(C-2), 79.8 (C-3), 39.6 (C-4), 56.0 (C-5), 19.0

(C-6), 33.3 (C-7), 40.0 (C-8), 48.4 (C-9), 37.5

(C-10), 23.8 (C-11), 122.8 (C-12), 144.2 (C-13),

42.0 (C-14), 28.4 (C-15), 23.7 (C-16), 46.5

(C-17), 42.0 (C-18), 46.5 (C-19), 31.1 (C-20),

34.5 (C-21), 33.2 (C-22), 28.7 (C-23), 16.5

(C-24), 16.0 (C-25), 18.0 (C-26), 26.0 (C-27),

184.2 (C-28), 33.2 (C-29), 23.8 (C-30).

\section{Experimental animals}

Pregnant Sprague-Dawley rats for primary neuronal culture and male ICR mice for the passive avoidance test were supplied by Daehan BioLink Co., Ltd. (Chungbuk, Korea) and housed in an environmentally controlled room at $22 \pm 2{ }^{\circ} \mathrm{C}$, with a relative humidity of $55 \pm 5 \%$, a 12-h light/dark cycle, and food and water ad libitum. The procedures involving experimental animals complied with the animal care guidelines of the National Institutes of Health and the animal ethics committee of Chungbuk National University.

\section{Induction of neurotoxicity in primary cultures of rat cerebral cortical neurons}

Primary cortical neuron cultures were prepared using embryonic day 15 - 16 Sprague-Dawley rat fetuses, as described previously $(24,25)$. Neurotoxicity experiments were performed on neurons after $3-4$ days in culture. Cultured neurons were treated with $10 \mu \mathrm{M} \mathrm{A} \beta(25-35)$ (Bachem, Bubendorf, Switzerland) in serum-free DMEM (Sigma, St. Louis, MO, USA) at $37^{\circ} \mathrm{C}$ for $36 \mathrm{~h}$ (unless otherwise indicated) to produce neurotoxicity. An $\mathrm{A} \beta(25-35)$ stock solution of $2 \mathrm{mM}$ was prepared in sterile distilled water, stored at $-20^{\circ} \mathrm{C}$, and incubated for more than 2 days at $37^{\circ} \mathrm{C}$ to aggregate before use. A. cordata and oleanolic acid were dissolved in DMSO at concentrations of $10 \mathrm{mg} / \mathrm{ml}$ and $10 \mathrm{mM}$, respectively, and further diluted in experimental buffers. The final concentration of DMSO was $\leq 0.1 \%$, which did not affect cell viability. For each experiment, A. cordata, oleanolic acid, $N^{\mathrm{G}}$-nitro-L-arginine methyl ester (LNAME; Sigma), (5R,10S)-(+)-5-methyl-10,11-dihydro$5 H$-dibenzo $[a, d]$ cyclohepten-5,10-imine (MK-801; RBI, Natick, MA, USA), and verapamil (Sigma) were applied $15 \mathrm{~min}$ prior to treatment with $10 \mu \mathrm{M} \mathrm{A} \beta(25-35)$. They were also present in the medium during $\mathrm{A} \beta(25-$
35) incubation.

Measurements of $A \beta(25-35)$-induced neuronal death and intracellular biochemical changes

The 3-(4,5-dimethylthiazol-2-yl)-2,5-diphenyl-tetrazolium bromide (MTT, Sigma) assay and Hoechst 33342 (Molecular Probes, Eugene, OR, USA) staining were performed to measure neuronal death $36-\mathrm{h}$ after exposure of cultured neurons to $10 \mu \mathrm{M} \mathrm{A} \beta(25-35)$, as previously described $(24,25)$. Changes in $\left[\mathrm{Ca}^{2+}\right]_{\mathrm{i}}$ were measured with Fluo-4 AM (Molecular Probes), a calcium-sensitive fluorescent dye, using a laser scanning confocal microscope (TCS SP2 AOBS; Leica, Heidelberg $\mathrm{GmbH}$, Germany) with a 488-nm excitation argon laser and 515-nm long-pass emission filters $(24,25)$. To measure glutamate secreted into the medium, cells were treated with $10 \mu \mathrm{M} \mathrm{A} \beta(25-35)$ in a HEPES buffer containing $8.6 \mathrm{mM}$ HEPES, $154 \mathrm{mM} \mathrm{NaCl}, 5.6 \mathrm{mM}$ $\mathrm{KCl}, 2.3 \mathrm{mM} \mathrm{CaCl}_{2}$, and $10 \mathrm{mM}$ glucose at $\mathrm{pH} 7.4$; and glutamate secreted over $24 \mathrm{~h}$ was quantified by HPLC with an electrochemical detector (MF series; BAS, Westlafayette, IN, USA) (24). The microfluorescence of 2',7'-dichlorofluorescein, the fluorescent product of 2',7'-dichlorodihydrofluorescein diacetate $\left(\mathrm{H}_{2} \mathrm{DCF}-\mathrm{DA}\right.$, Molecular Probes), and a laser scanning confocal microscope (TCS SP2 AOBS, Leica) with 488-nm excitation and 510-nm emission filters were used to monitor the generation of ROS in neurons treated with $10 \mu \mathrm{M}$ $\mathrm{A} \beta(25-35)$ for $36 \mathrm{~h}(24,25)$.

\section{Examination of learning and memory}

Passive avoidance task: On day 1, A. cordata, donepezil (generously provided by Eisai Co., Ltd., Tokyo), and verapamil were administered to 5 -week-old ICR mice and $30 \mathrm{~min}$ later, the aggregated form of $\mathrm{A} \beta(25-$ 35) was administered i.c.v. using a microsyringe with a 27-gauge stainless-steel needle (Hamilton, Reno, NV, USA), the tip of which had been adjusted to a depth of $3 \mathrm{~mm}$. The needle was inserted unilaterally $2 \mathrm{~mm}$ to the right of the midline point equidistant from each eye, at an equal distance between the eyes and the ears, and perpendicular to the plane of the skull (26). The injection volume of $\mathrm{A} \beta(25-35)$ was $15 \mu \mathrm{l}(15 \mathrm{nmol})$. A. cordata (50 and $100 \mathrm{mg} / \mathrm{kg}$, p.o.) suspended in distilled water, donepezil ( $2 \mathrm{mg} / \mathrm{kg}$, p.o.), and verapamil $(20 \mathrm{mg} / \mathrm{kg}$, p.o.) were administered daily for 7 days. At $30 \mathrm{~min}$ after administration of A. cordata, donepezil and verapamil on day 7, mice were trained on a one-trail step-through passive avoidance task. The passive avoidance box was divided into two chambers separated by a guillotine door and equipped with a grid floor and a shock generator (Gemini Avoidance System, San Diego, CA, USA). During the acquisition trial, each mouse was placed 
into the start chamber and kept in the dark until it was illuminated. After $50 \mathrm{~s}$, the start chamber was illuminated and the door was opened for the mouse to move into the dark chamber freely. Immediately after the mouse entered the dark chamber, the door was closed and the mouse received an inescapable electric shock $(0.3 \mathrm{~mA}, 2 \mathrm{~s})$. In the retention trial given $24 \mathrm{~h}$ after the acquisition trial, the mouse was again placed in the chamber and illuminated $50 \mathrm{~s}$ later, and the time it took until it re-entered the dark chamber was measured (the step-through latency, maximum testing limit was $300 \mathrm{~s}$ ). To test for any possible effect of $\mathrm{A} \beta(25-35)$ on motor function, the locomotor activity of the animals was measured using a photobeam monitoring system (AM1051; Benwick Electronics, Benwick, UK), and motor coordination was measured using a rota-rod apparatus (Daejong Inc., Seoul, Korea). Each mouse was placed in the center of the activity cage and the total number of beam interruptions was registered for $5 \mathrm{~min}$. Then the mouse was put on the rota-rod for $2 \mathrm{~min}$ and the number of falls from the rod was noted.

Brain cholinesterase activity measurement: After the retention trial of the passive avoidance test, the mice were anesthetized deeply with diethyl ether and their brains were removed. Whole brain homogenates of cholinesterase preparation were prepared in a 50 -fold volume of $10 \mathrm{mM}$ phosphate buffer on ice. The concentration of acetylcholine (ACh) added as substrate of and hydrolyzed by cholinesterase was determined by the method of Hestrin (27) with a slight modification to measure brain cholinesterase activity. Briefly, aliquots $(0.5 \mathrm{ml})$ of brain homogenates were mixed with $1 \mathrm{~mL}$ of $8 \mathrm{mM}$ ACh, $0.4 \mathrm{ml}$ of $0.1 \mathrm{mM}$ phosphate buffer, and $0.1 \mathrm{ml}$ distilled water. After adequate blending, the mixtures were incubated at $37^{\circ} \mathrm{C}$ for $30 \mathrm{~min}$. The reaction was stopped by the addition of $2 \mathrm{ml}$ alkalized hydroxylamine, and $0.5 \mathrm{ml}$ of $4 \mathrm{~N} \mathrm{HCl}$ and $0.5 \mathrm{ml}$ of $0.37 \mathrm{M} \mathrm{FeCl}_{3}$ were added to the reaction mixture. Absorbance was read at $540 \mathrm{~nm}$ and calibrated with a blank and an ACh standard.

Histological examination: After the retention trial of the passive avoidance test, five mice in each group were anesthetized deeply with diethyl ether, and then the brains were perfused transcardially with cold heparinized phosphate-buffered saline (PBS, pH 7.2), removed, and fixed in $10 \%(\mathrm{v} / \mathrm{v})$ formalin solution in PBS for $72 \mathrm{~h}$. The brains were then embedded in paraffin and representative coronal sections $(5-\mu \mathrm{m}$-thick) that included the dorsal hippocampus were obtained using a rotary microtome (HM 315; Microm GmbH, Walldorf, Germany). The tissue sections were stained with hematoxylin and eosin (H\&E). The sections were dehydrated, mounted in Canada balsam, and then analyzed using a brightfield microscope (CX21; Olympus, Tokyo). The number of pyramidal cells in the CA1 region of the hippocampus was counted.

\section{Statistical analyses}

Data are expressed as the mean \pm S.E.M. and statistical significance was assessed by one-way analysis of variance (ANOVA) and Tukey's tests. $P<0.05$ was considered significant.

\section{Results}

A. cordata and oleanolic acid inhibit $A \beta(25-35)$ induced neuronal cell death

The concentration of $10 \mu \mathrm{M}$ was used for determining $\mathrm{A} \beta(25-35)$-induced neuronal cell damage in the present experiments based on our previous results (28). When cortical neurons were exposed to $10 \mu \mathrm{M} \mathrm{A} \beta(25-35)$ for $36 \mathrm{~h}$, absorbance in the MTT assay was $67.8 \pm 1.3 \%$ of the control level (untreated cells) (Fig. 2), indicating that $\mathrm{A} \beta(25-35)$ caused neuronal cell death. In cultures treated with $A$. cordata $(1,5$, or $10 \mu \mathrm{g} / \mathrm{ml})$, the $\mathrm{A} \beta(25$ $35)$-induced neuronal death was significantly reduced (absorbance: $84.4 \pm 1.7 \%$ of the control with $10 \mu \mathrm{g} / \mathrm{ml}$ A. cordata). To determine which components of A. cordata exhibit neuroprotective activity, we examined several compounds including diterpenes, triterpenes such as oleanolic acid, and saponins isolated from A. cordata (data not shown). Of these, only oleanolic acid protected against $\mathrm{A} \beta(25-35)$-induced neurotoxicity

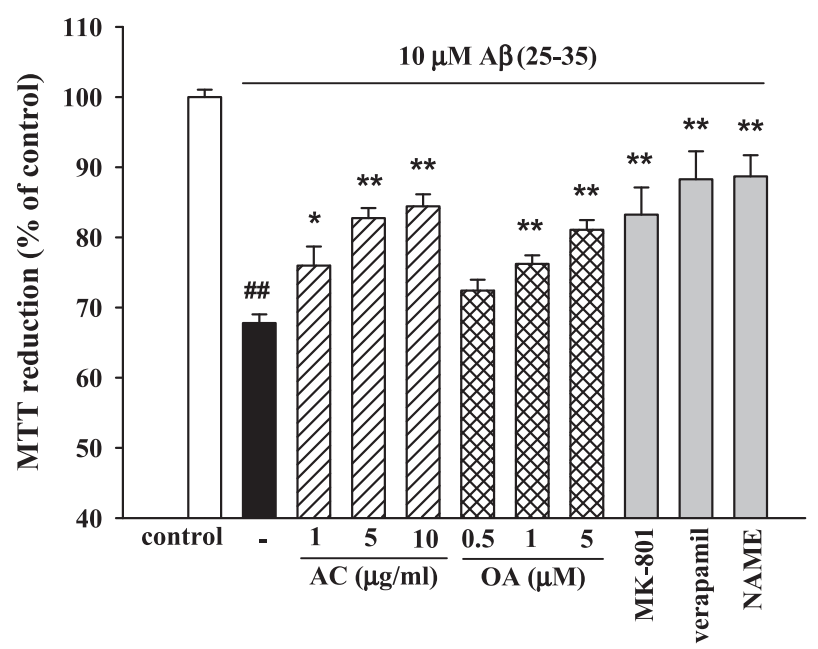

Fig. 2. Inhibitory effects of $A$. cordata (AC) and oleanolic acid $(\mathrm{OA})$ on $\mathrm{A} \beta(25-35)$-induced neuronal cell death in cultured cortical neurons. Neuronal cell death was measured using the MTT assay. The MTT absorbance from untreated cells was normalized to $100 \%$. Results are expressed as the mean \pm S.E.M. of data obtained from 3 independent experiments performed in triplicate. ${ }^{\#} P<0.01$ vs. control; ${ }^{*} P<0.05,{ }^{*} P<0.01$ vs. $10 \mu \mathrm{M} \mathrm{A} \beta(25-35)$. 


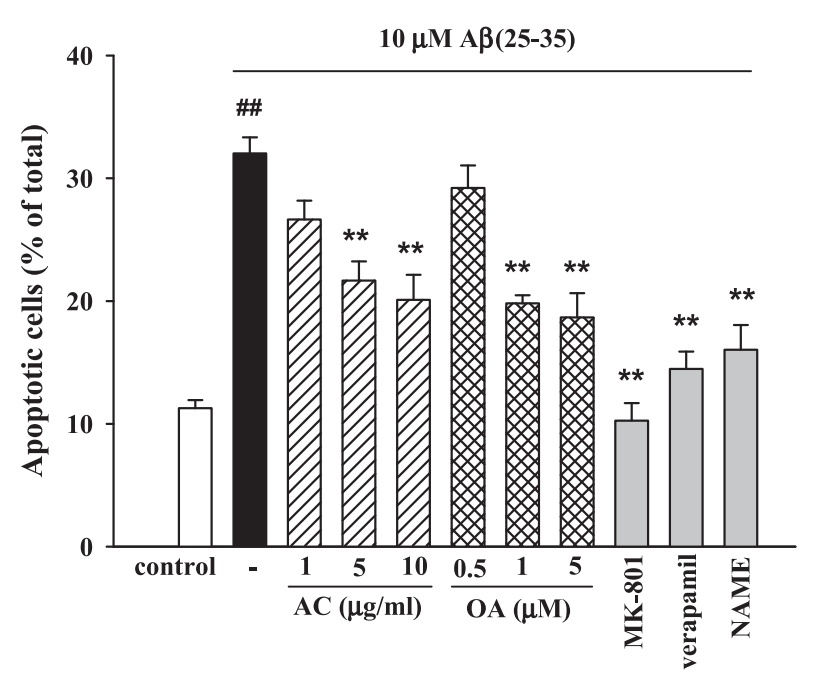

Fig. 3. Inhibitory effects of A. cordata (AC) and oleanolic acid (OA) on $\mathrm{A} \beta(25-35)$-induced apoptosis of cultured cortical neurons. Apoptotic cells measured by Hoechst 33342 staining were counted in 5 to 6 fields per well. Results are apoptotic cells as a percentage of the total number of cells expressed as the mean \pm S.E.M. of data obtained from 4 independent experiments performed in 2 to 3 wells. ${ }^{\#} P<0.01$ vs. control, ${ }^{* *} P<0.01$ vs. $10 \mu \mathrm{M} \mathrm{A} \beta(25-35)$.

in cultured cortical neurons. Pretreatment of cortical neurons with 1 and $5 \mu \mathrm{M}$ oleanolic acid reduced the neuronal death induced by $10 \mu \mathrm{M} \mathrm{A} \beta(25-35)$ (absorbance: $76.2 \pm 1.2 \%$ and $81.1 \pm 1.4 \%$ of control, respectively; Fig. 2). MK-801 (10 $\mu \mathrm{M})$, verapamil $(5 \mu \mathrm{M})$, and L-NAME $(1 \mathrm{mM})$ also inhibited the $10 \mu \mathrm{M} \mathrm{A} \beta(25-35)$ induced neuronal death (absorbance: 83.2 $\pm 3.9 \%$, $88.3 \pm 4.0 \%$, and $88.7 \pm 3.0 \%$ of the control, respectively; Fig. 2).

Hoechst 33342 staining was used to detect condensed or fragmented DNA, which is indicative of $\mathrm{A} \beta(25-35)$ induced neuronal apoptotic death. Treatment of neurons with $10 \mu \mathrm{M} \mathrm{A} \beta(25-35)$-induced apoptosis in $32.4 \pm 0.8 \%$ of cultured cortical neurons, compared with $11.1 \pm 0.7 \%$ in control cultures. The addition of A. cordata (10 $\mu \mathrm{g} / \mathrm{ml})$ or oleanolic acid $(5 \mu \mathrm{M})$ significantly decreased A $\beta(25-35)$-induced apoptotic cell death to $20.1 \pm 2.0 \%$ and $18.7 \pm 2.0 \%$ of all neurons, respectively (Fig. 3). Apoptotic cell death induced by $10 \mu \mathrm{M} \mathrm{A} \beta(25-35)$ was also blocked by pretreatment with MK-801 $(10 \mu \mathrm{M})$, verapamil $(5 \mu \mathrm{M})$, and L-NAME $(1 \mathrm{mM})$ to $10.3 \pm 1.4 \%$, $14.5 \pm 1.4 \%$, and $16.0 \pm 2.0 \%$, respectively (Fig. 3).

\section{A. cordata and oleanolic acid inhibit AB(25-35)- induced $\left[\mathrm{Ca}^{2+}\right]_{i}$ elevation}

Increases in $\left[\mathrm{Ca}^{2+}\right]_{i}$ have been associated with $\mathrm{A} \beta$ induced cell death. In our cell cultures, $\left[\mathrm{Ca}^{2+}\right]_{\mathrm{i}}$ rapidly increased in response to treatment with $10 \mu \mathrm{M} \mathrm{A} \beta(25-$ 35 ) and then showed a slow and gradual decrease over $10 \mathrm{~min}$ (Fig. 4). In contrast, pretreatment with

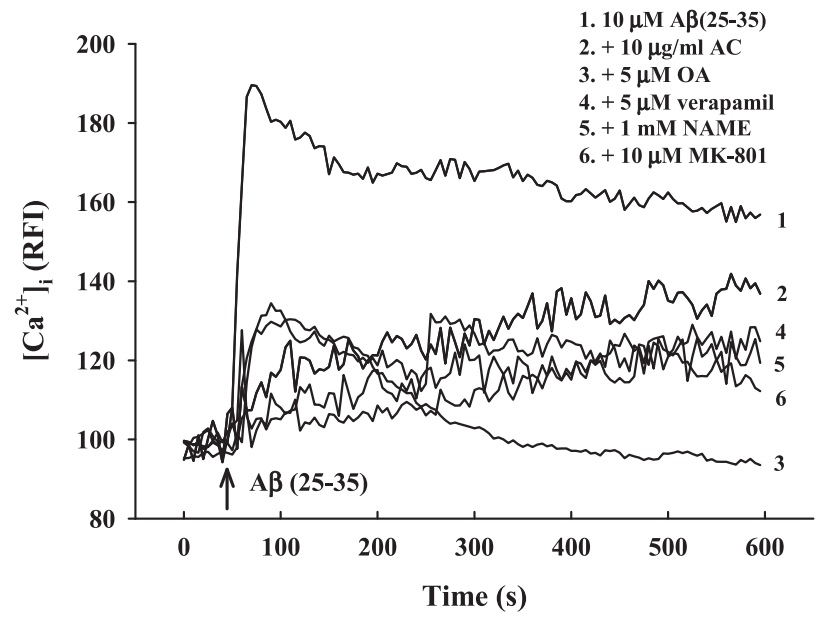

Fig. 4. Inhibitory effects of A. cordata (AC) and oleanolic acid $(\mathrm{OA})$ on $\mathrm{A} \beta(25-35)$-induced $\left[\mathrm{Ca}^{2+}\right]_{\mathrm{i}}$ elevation in cultured cortical neurons. $\left[\mathrm{Ca}^{2+}\right]_{\mathrm{i}}$ was monitored using Fluo-4 AM dye and a confocal laser scanning microscope. All images were processed to analyze changes in $\left[\mathrm{Ca}^{2+}\right]_{\mathrm{i}}$ at the single cell level. Results are expressed as the relative fluorescence intensity (RFI). Each trace shows a single cell that is representative of at least 3 independent experiments.

A. cordata $(10 \mu \mathrm{g} / \mathrm{ml})$, oleanolic acid $(5 \mu \mathrm{M})$, MK-801 $(10 \mu \mathrm{M})$, verapamil $(5 \mu \mathrm{M})$, and L-NAME $(1 \mathrm{mM})$ significantly inhibited the increase of $\left[\mathrm{Ca}^{2+}\right]_{\mathrm{i}}$ induced by $10 \mu \mathrm{M} \mathrm{A} \beta(25-35)$ throughout the measurement period. A. cordata and the other compounds did not affect basal $\left[\mathrm{Ca}^{2+}\right]_{\mathrm{i}}$.

A. cordata and oleanolic acid inhibit Aß(25-35)induced elevation of glutamate release

We next quantified the glutamate released into the extracellular medium after treatment with $10 \mu \mathrm{M}$ $\mathrm{A} \beta(25-35)$ for $24 \mathrm{~h}$. As shown in Fig. 5, $10 \mu \mathrm{M} \mathrm{A} \beta(25-$ 35) elevated the basal glutamate level from $3.39 \pm 0.29$ $\mu \mathrm{M}$ in control neurons to $6.77 \pm 0.41 \mu \mathrm{M}$. A. cordata (5 and $10 \mu \mathrm{g} / \mathrm{ml}$ ) significantly blocked the $\mathrm{A} \beta(25-35)$ induced elevation of glutamate release, resulting in maximal values of $4.17 \pm 0.39$ and $3.78 \pm 0.24 \mu \mathrm{M}$, respectively. Oleanolic acid ( 1 and $5 \mu \mathrm{M})$ also inhibited the $\mathrm{A} \beta(25-35)$-induced elevation of glutamate release, resulting in maximal values of $4.16 \pm 0.97$ and $3.70 \pm$ $0.55 \mu \mathrm{M}$, respectively.

\section{A. cordata and oleanolic acid inhibit Aß(25-35)-} induced ROS generation

To clarify the involvement of oxidative stress in $\mathrm{A} \beta$ neurotoxicity, we measured the accumulation of ROS after the exposure of the cells to $\mathrm{A} \beta(25-35)$ for $36 \mathrm{~h}$. In $\mathrm{H}_{2}$ DCF-DA-loaded cerebral cortical neurons, $10 \mu \mathrm{M}$ $\mathrm{A} \beta(25-35)$ increased the fluorescence intensity, indicating that ROS were generated. In neurons treated with 


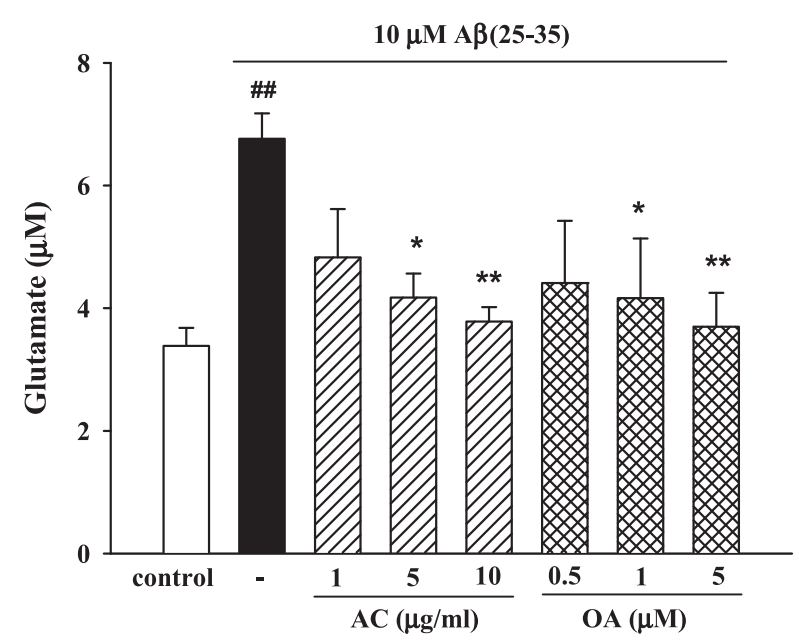

Fig. 5. Inhibitory effects of A. cordata (AC) and oleanolic acid $(\mathrm{OA})$ on $\mathrm{A} \beta(25-35)$-induced glutamate release in cultured cortical neurons. The amount of glutamate released over $24 \mathrm{~h}$ was measured by HPLC with an electrochemical detector. Results are expressed as the mean \pm S.E.M. of data obtained from 3 independent experiments performed in 2 to 3 wells. ${ }^{\#} P<0.01$ vs. control; ${ }^{*} P<0.05,{ }^{* *} P<0.01$ vs. $10 \mu \mathrm{M} \mathrm{A} \beta(25-35)$.

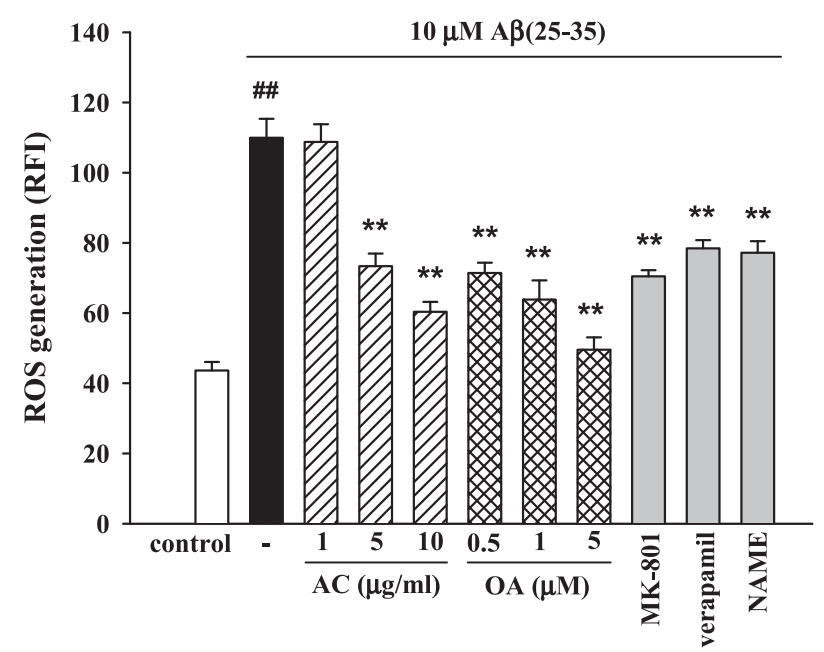

Fig. 6. Inhibitory effect of $A$. cordata (AC) and oleanolic acid (OA) on $\mathrm{A} \beta(25-35)$-induced ROS generation in cultured cortical neurons. Results are expressed as the mean \pm S.E.M. of RFI obtained from 3 independent experiments performed in 2 to 3 wells. ${ }^{\#} P<0.01$ vs. control; ** $P<0.01$ vs. $10 \mu \mathrm{M} \mathrm{A} \beta(25-35)$.

$10 \mu \mathrm{M} \mathrm{A} \beta(25-35)$, the relative fluorescence increased approximately 2.5 -fold to $108.8 \pm 7.0$ compared with the value in control neurons $(43.3 \pm 2.7$; Fig. 6$)$. The $\mathrm{A} \beta(25-35)$-induced increase in ROS generation was significantly inhibited by $A$. cordata $(5$ and $10 \mu \mathrm{g} / \mathrm{ml})$ and oleanolic acid $(0.5,1$, and $5 \mu \mathrm{M})$. MK-801 $(10 \mu \mathrm{M})$, verapamil $(5 \mu \mathrm{M})$, and L-NAME $(1 \mathrm{mM})$ also significantly blocked the $\mathrm{A} \beta(25-35)$-induced increase of ROS generation (Fig. 6).

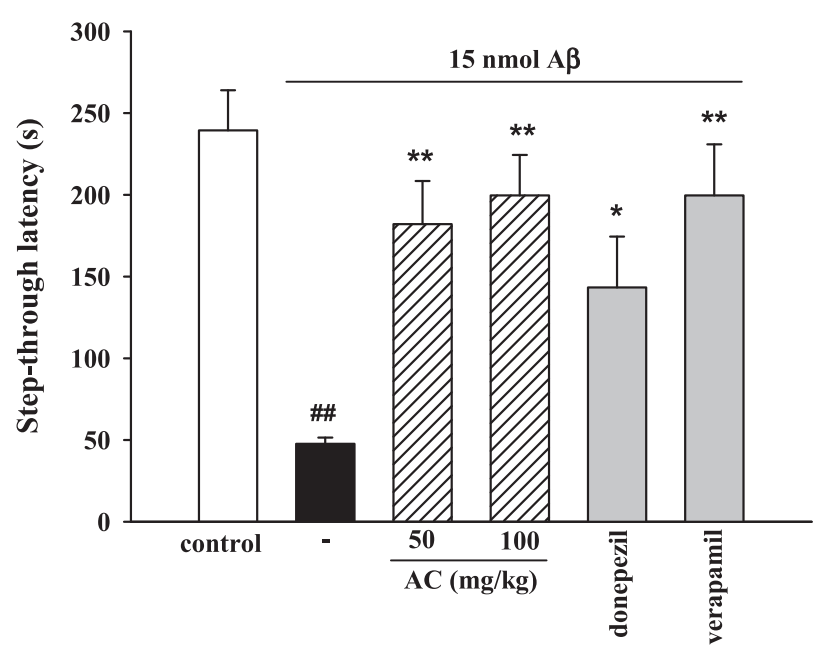

Fig. 7. Protective effect of $A$. cordata (AC) against $\mathrm{A} \beta(25-35)$ induced memory impairment in mice. The learning and memory performance was assessed by the passive avoidance test. Values are expressed as the mean \pm S.E.M. of step-through latency $(n=10)$. ${ }^{\#} P<0.01$ vs. control; ${ }^{*} P<0.05,{ }^{*} P<0.01$ vs. $10 \mu \mathrm{M} \mathrm{A} \beta(25-35)$.

A. cordata inhibits $A \beta(25-35)$-induced memory impairment and neuronal death in mice

In the initial acquisition trial of the passive avoidance task, the step-through latency did not differ among the 6 groups [control, $15 \mathrm{nmol} \mathrm{A} \beta(25-35), 15 \mathrm{nmol} \mathrm{A} \beta(25-$ $35)+50 \mathrm{mg} / \mathrm{kg}$ A. cordata, $15 \mathrm{nmol} \mathrm{A} \beta(25-35)+100$ $\mathrm{mg} / \mathrm{kg}$ A. cordata, $15 \mathrm{nmol} \mathrm{A} \beta(25-35)+2 \mathrm{mg} / \mathrm{kg}$ donepezil, and $15 \mathrm{nmol} \mathrm{A} \beta(25-35)+20 \mathrm{mg} / \mathrm{kg}$ verapamil; data not shown]. The step-through latency of the A $\beta(25-35)$-treated group in the retention trial decreased significantly to $47.6 \pm 3.8 \mathrm{~s}$, compared with $239.5 \pm$ $24.5 \mathrm{~s}$ in the control group, indicating that $\mathrm{A} \beta(25-35)$ impaired memory in mice. Chronically administered $A$. cordata markedly protected against the memory impairment produced by $\mathrm{A} \beta(25-35)$. The step-through latency in groups administered $A$. Cordata was $182.1 \pm$ $26.3 \mathrm{~s}$ and $199.6 \pm 24.8 \mathrm{~s}$ at doses of 50 and $100 \mathrm{mg} / \mathrm{kg}$, respectively (Fig. 7). Chronic administration of donepezil $(2 \mathrm{mg} / \mathrm{kg})$, a cholinesterase inhibitor, and verapamil $(20 \mathrm{mg} / \mathrm{kg})$ also protected against $\mathrm{A} \beta(25-35)$-induced memory impairment (step-through latency: $143.3 \pm 31.2$ and 199.6 \pm 31.3 , respectively; Fig. 7). MK-801 (0.1 mg $/ \mathrm{kg}$, i.p.) and L-NAME (50 mg $/ \mathrm{kg}$, s.c.), however, failed to inhibit $\mathrm{A} \beta(25-35)$-induced memory impairment (data not shown). To elucidate whether $A$. cordata affects general motor functions, we measured spontaneous locomotor activity and motor coordination in the mice. Neither $A$. Cordata nor A $\beta(25-35)$ significantly affected locomotor and rota-rod activity (data not shown), indicating that the observed improvement of memory by A. cordata was not due to immobility.

Exposure to $15 \mathrm{nmol} \mathrm{A} \beta(25-35)$ produced a signifi- 
Table 1. Effect of A. cordata (AC) on brain cholinesterase activity in mice

\begin{tabular}{lcc}
\hline Group & Dose & $\begin{array}{c}\text { Cholinesterase activity } \\
{[\mu \mathrm{mol} / \mathrm{h} \text { per brain }(1 \mathrm{~g})]}\end{array}$ \\
\hline Control & - & $446.80 \pm 2.66$ \\
$\mathrm{~A} \beta(25-35)$ & $15 \mathrm{nmol} / \mathrm{animal}$ & $463.06 \pm 1.78^{\#}$ \\
$+\mathrm{AC}$ & $50 \mathrm{mg} / \mathrm{kg}$ & $456.87 \pm 4.73$ \\
$+\mathrm{AC}$ & $100 \mathrm{mg} / \mathrm{kg}$ & $443.17 \pm 2.60^{* *}$ \\
\hline
\end{tabular}

${ }^{a}$ Results are expressed as the mean \pm S.E.M. of acetylcholine concentration hydrolyzed by the cholinesterase preparation of brain homogenate for $1 \mathrm{~h}$ ( $\mathrm{n}=5$ mice/group). ${ }^{\#} P<0.05$ vs. control, ${ }^{* *} P<0.01$ vs. $\mathrm{A} \beta(25-35)$ alone.

cant increase in cholinesterase activity in the brain. In the group consuming $100 \mathrm{mg} / \mathrm{kg}$ A. cordata, the cholinesterase activity was significantly decreased compared with the $\mathrm{A} \beta(25-35)$ group (Table 1$)$.

We examined the subsequent histological changes in the hippocampus of $\mathrm{A} \beta(25-35)$-injected mice. As compared with vehicle-treated mice (Fig. 8A: a and f, cell number $247.5 \pm 10.7)$, the number of CA1 pyramidal cells decreased in $\mathrm{A} \beta(25-35)$-treated mice (Fig. 8A: $\mathrm{b}$ and g, cell number $146.5 \pm 5.7$ ). Administration of 50 and $100 \mathrm{mg} / \mathrm{kg} \mathrm{A}$. cordata, $2 \mathrm{mg} / \mathrm{kg}$ donep- ezil, and $20 \mathrm{mg} / \mathrm{kg}$ verapamil for 7 days protected the hippocampus against the $\mathrm{A} \beta(25-35)$-induced neuronal loss (cell number: 167.5 $\pm 3.7,207.8 \pm 3.6,180.0 \pm 7.1$, and $227.5 \pm 10.5$, respectively; Fig. $8 \mathrm{~B}$ ).

\section{Discussion}

As an active partial fragment of $\mathrm{A} \beta, \mathrm{A} \beta(25-35)$ forms a $\beta$-sheet structure and induces neuronal cell death, neuritic atrophy, synaptic loss, and memory impairment, although it is not found in the AD brain $(15,26,29,30)$. The present study demonstrated that $\mathrm{A} \beta(25-35)$ causes $\left[\mathrm{Ca}^{2+}\right]_{\mathrm{i}}$ increase, glutamate release, ROS generation, and neuronal cell death in cultured cortical neurons, all of which were blocked by treatment with MK-801, an NMDA antagonist; verapamil, an L-type $\mathrm{Ca}^{2+}$ channel blocker; and L-NAME, a NOS inhibitor. These results supporting the involvement of NMDA glutamatereceptor activation, increased $\mathrm{Ca}^{2+}$ influx, and generation of ROS in $\mathrm{A} \beta(25-35)$-induced neurotoxicity in cultured neurons are consistent with the results of other studies $(3,31-33)$. Regardless of the relative contribution of these events to $\mathrm{A} \beta(25-35)$-induced neurotoxicity, the primary event following $\mathrm{A} \beta(25-35)$ treatment of cultured neurons has been suggested to be $\mathrm{Ca}^{2+}$ influx,
(A)
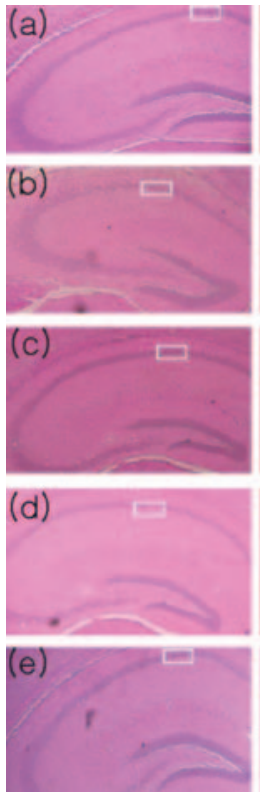
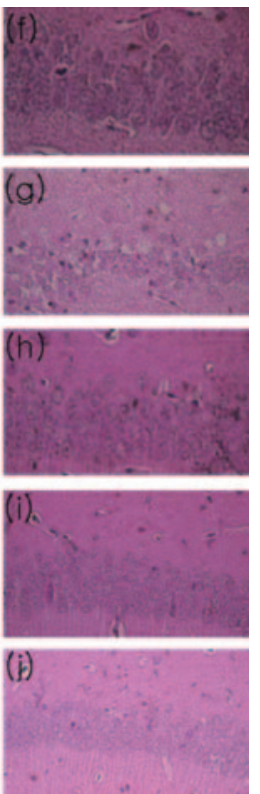

(B)

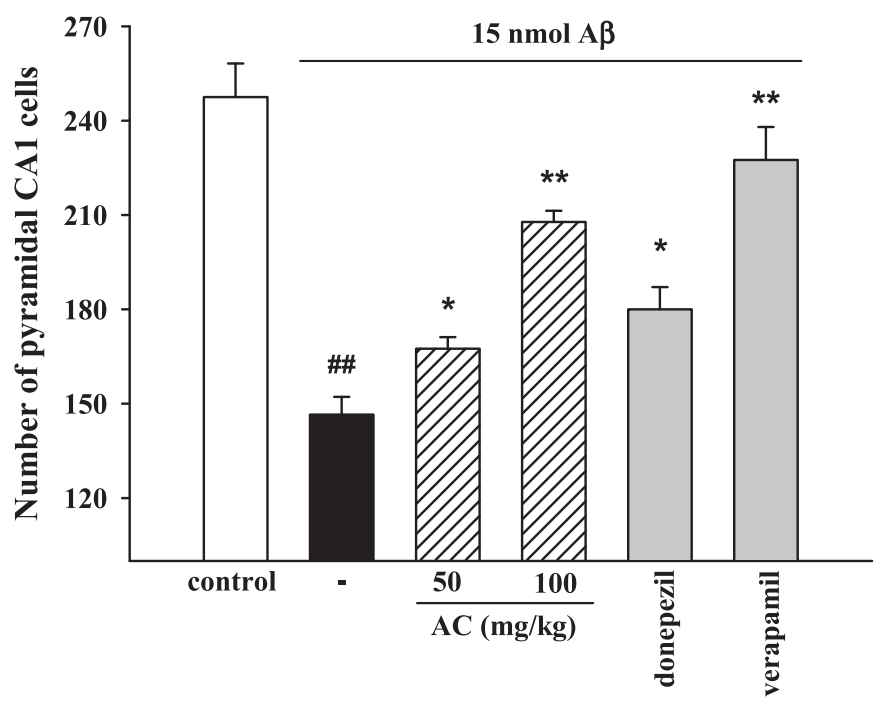

Fig. 8. Representative photomicrographs of the hippocampus and CA1 region (A) and histogram of CA1 pyramidal cell numbers (B) representing the inhibitory effect of $A$. cordata (AC) on A $\beta(25-35)$-induced hippocampal damage in mice. Brain sections were stained with H\&E. Pathological features of brain sections 7 days after i.c.v. injection of $15 \mathrm{nmol} A \beta(25-35)$ were observed using a brightfield microscope. Panels a and f represent the control group; panels b and g, A $\beta$-injected group; panels c and $\mathrm{h}, \mathrm{A} \beta+100 \mathrm{mg} / \mathrm{kg} \mathrm{AC}$ group; panels $\mathrm{d}$ and $\mathrm{i}, \mathrm{A} \beta+2 \mathrm{mg} / \mathrm{kg}$ donepezil group; panels e and $\mathrm{j}, \mathrm{A} \beta+20 \mathrm{mg} / \mathrm{kg}$ verapamil group. Panels a - e represent the hippocampus $(\times 40)$; panels $\mathrm{f}-\mathrm{j}$, CA 1 region $(\times 400)$. Values are expressed as the mean \pm S.E.M of cell numbers from five mice. ${ }^{\# \#} P<0.01$ vs. control; ${ }^{*} P<0.05$, ${ }^{* *} P<0.01$ vs. A $\beta(25-35)$. 
apparently via L-type voltage-dependent $\mathrm{Ca}^{2+}$ channels (L-VDCC), because blockade of this channel or $\mathrm{Ca}^{2+}$ chelation prevents other consequences $(5,32)$. Vitamin E, an antioxidant, blocks the $\mathrm{A} \beta$-induced generation of ROS but not $\mathrm{Ca}^{2+}$ influx, whereas reduction of extracellular $\mathrm{Ca}^{2+}$ inhibits both the $\mathrm{A} \beta$-induced increase in intracellular $\mathrm{Ca}^{2+}$ and the generation of ROS, indicating that ROS generation is a consequence of $\mathrm{Ca}^{2+}$ accumulation (3). Many experiments $(5,31,34)$, however, have demonstrated that free radicals are responsible for the increase of $\left[\mathrm{Ca}^{2+}\right]_{i}$. The ROS-induced membrane damage causes further $\mathrm{Ca}^{2+}$ influx and the resulting increase in $\mathrm{Ca}^{2+}$ influx in turn induces the generation of further ROS. In the present study, both verapamil and L-NAME inhibited the $\mathrm{A} \beta(25-35)$ induced $\left[\mathrm{Ca}^{2+}\right]_{i}$ increase and ROS generation. We therefore hypothesized that $\left[\mathrm{Ca}^{2+}\right]_{i}$ increase and ROS generation were almost simultaneous early events induced by $\mathrm{A} \beta(25-35)$ and were responsible for $\mathrm{A} \beta(25-$ $35)$-induced neuronal death in this culture system. A. cordata inhibited the $\mathrm{A} \beta(25-35)$-induced $\left[\mathrm{Ca}^{2+}\right]_{\mathrm{i}}$ increase, glutamate release, ROS generation, and neuronal cell death in cultured cortical neurons in the current study. This result indicates that $A$. cordata might prevent $\mathrm{Ca}^{2+}$ entry through VDCC- and/or NMDAreceptor-coupled channels to inhibit $\mathrm{A} \beta(25-35)$ induced neuronal death, although the mechanism by which A. cordata blocks the channels is not clear. A. cordata has been reported to possess antioxidant principles such as those of diterpenes and triterpenes $(35,36)$, suggesting that inhibition of $\mathrm{A} \beta(25-35)$ induced neuronal death by $A$. cordata might be due to their ROS-scavenging activity. Furthermore, diterpenes and triterpenes have been demonstrated to inhibit $\mathrm{Ca}^{2+}$ entry through $\mathrm{Ca}^{2+}$ channels $(37,38)$, indicating that these compounds, including oleanolic acid, may contribute to the inhibitory activity of $A$. cordata on $\mathrm{Ca}^{2+}$ entry through VDCC- and/or NMDA-receptor-coupled channels to inhibit $\mathrm{A} \beta(25-35)$-induced neuronal death. Further study to elucidate the precise mechanism should be performed.

Many researchers have demonstrated that $\mathrm{A} \beta$ triggers apoptotic degeneration in in vitro neuronal experiments $(3,39)$. In the present work, cultured cortical neurons exposed to $\mathrm{A} \beta(25-35)$ for $36 \mathrm{~h}$ showed increased chromatin condensation, a typical feature of apoptotic cell death, which was reduced by $A$. cordata. A $\beta$ induced apoptosis was also associated with $\mathrm{COX}-2$ upregulation, and COX has been suggested to be an important source of ROS in the pathologic brain (40, 41). Therefore, the protective effect of $A$.cordata against the $\mathrm{A} \beta$-induced neurotoxicity might result from the inhibition of COX-1 and COX-2 $(20,21)$. A. cordata inhibits chondrocyte apoptosis through the downregulation of JNK and p38 MAP kinase signaling and the inhibition of caspase-3 activity (42). A. cordata could therefore prevent any step of the apoptotic cascade. The molecular mechanism for the prevention of neuronal apoptosis by $A$. cordata should be further clarified.

I.c.v. injection of $\mathrm{A} \beta(25-35)$ into experimental rodents induces memory impairment in different behavioral paradigms, including spontaneous alternation, the water maze, and passive avoidance $(26,43)$. A $\beta(25-35)$ preferentially impairs spatial and non-spatial short-term memory, and these effects remain evident up to 6 months after even a single i.c.v. injection of the peptide (44). Memory impairment in the passive avoidance test was also confirmed in mice 7 days after the i.c.v. injection of $\mathrm{A} \beta(25-35)$ in the present work. Chronic treatment with $A$. cordata $(50$ and $100 \mathrm{mg} / \mathrm{kg}$, p.o.) effectively protected the mice against $\mathrm{A} \beta(25-35)$ induced memory deficit. Moreover, $A$. cordata treatment significantly prevented $\mathrm{A} \beta(25-35)$-induced neuronal damage in the hippocampus, as observed by histological examination. Especially, $\mathrm{A} \beta(25-35)$ induced a significant cell loss in the CA1 pyramidal cell layer, as evidenced by others $(45,46)$, and $A$. cordata protected against this. These results were consistent with its protective effect against $\mathrm{A} \beta(25-35)$-induced neurotoxicity in vitro. $\mathrm{A} \beta$ accumulation associated with cognitive impairment in $\mathrm{AD}$ is accompanied by an increase in cholinesterase activity (47); consistent with this, the increase of cholinesterase activity by A $\beta(25-35)$ in the brain was inhibited by A. cordata in the present study. The present study also demonstrated the protection by donepezil, a cholinesterase inhibitor, against A $\beta(25-35)$-induced memory impairment. In addition, A. cordata administration significantly prevented scopolamine-induced learning and memory impairment, reducing escape latency during training in the Morris water maze test, a spatial task that is sensitive to impaired cholinergic function in the hippocampus (48) (data not shown). Taken together, these results suggest that $A$. cordata increases cholinergic activity.

On the other hand, other studies have indicated that oxidative stress is responsible for the onset of the cognitive dysfunction as well as the progression of $\mathrm{AD}$ $(31,49)$. Elevated levels of $\mathrm{A} \beta$ induce oxidative stress, increasing the appearance of ROS such as superoxide $\left(\mathrm{O}_{2}^{-}\right)$and $\mathrm{NO}$ and subsequently producing $\mathrm{ONOO}^{-}$by a rapid interaction, could mediate the damage seen in $\mathrm{AD}$ $(49,50)$. A scavenger of $\mathrm{ONOO}^{-}$protects against $\mathrm{A} \beta(25-35)$-induced memory impairment (51), and antioxidants such as $\alpha$-tocopherol protect against cytotoxicity in vitro as well as against learning and memory deficits induced by $\mathrm{A} \beta(12)$. In the present study, $10 \mu \mathrm{M}$ 
$\mathrm{A} \beta(25-35)$ significantly increased the ROS level in cultured neurons, and this was inhibited by $A$. cordata. In addition, Aralia species contain antioxidant components $(35,36)$. Therefore, it is possible that the favorable effect of $A$. cordata on $\mathrm{A} \beta(25-35)$-induced cognitive deficits can be attributed to the inhibition of ROS generation. The attenuation of memory impairment by A. cordata is likely to be a corollary of its inhibition of A $\beta(25-35)$-induced $\left[\mathrm{Ca}^{2+}\right]_{\mathrm{i}}$, because memantine was demonstrated to have therapeutic benefits on $\mathrm{AD}$ due to its affinity for the NMDA-receptor $\mathrm{Ca}^{2+}$ channel (52). Moreover, the possible contribution of the blocking effect of donepezil, an acetylcholinesterase inhibitor, on the voltage-gated $\mathrm{Ca}^{2+}$ channels to the neuroprotective effect in $A D$ was reported (53). In support of this hypothesis, verapamil, an L-type $\mathrm{Ca}^{2+}$ channel blocker, inhibited $\mathrm{A} \beta(25-35)$-induced memory impairment in the present study. Quartermain and Garcia deSoria also reported enhancing effects of $\mathrm{Ca}^{2+}$-channel antagonists on passive avoidance and maze learning $(54,55)$, although there are controversial reports about the mnemonic effect of $\mathrm{Ca}^{2+}$-channel antagonists $(56,57)$. However, we failed to demonstrate the inhibitory effects of MK-801 and L-NAME on A $\beta(25-35)$-induced memory deficits. These results are consistent with the reports showing the impairment of learning and memory by NMDA-receptor antagonists and the role of $\mathrm{NO}$ on learning and memory in animals $(58-61)$.

Oleanolic acid isolated from the aerial part of $A$. cordata also protected against $\mathrm{A} \beta(25-35)$-induced neuronal damage. Oleanolic acid was able to reduce the $\mathrm{A} \beta$-induced $\left[\mathrm{Ca}^{2+}\right]_{\mathrm{i}}$ increase, glutamate release, and ROS generation and, as a result, to attenuate neuronal apoptotic death in primary cultures of rat cortical neurons. Therefore, the inhibition by $A$. cordata of the $\mathrm{A} \beta(25-35)$-induced memory deficit as well as neuronal damage in cultures may be attributable, at least in part, to the beneficial effects of oleanolic acid. Oleanolic acid is found naturally in various medicinal herbs traditionally used for anti-inflammatory, analgesic, hepatoprotective, and cardiotonic effects (62) and in rats has been reported to protect against myocardial ischemia-reperfusion injury by enhancing antioxidant activity of the mitochondria mediated by glutathione and $\alpha$-tocopherol (63). Oleanolic acid has also been reported to have inhibitory activity against COX-1 and COX-2 (21). Although there has been no evidence up until now to show that oleanolic acid antagonizes $\mathrm{A} \beta(25-35)$ induced neurotoxicity, the present study demonstrated a novel pharmacological activity of oleanolic acid in neurons.

In conclusion, the protection against $\mathrm{A} \beta(25-35)-$ induced neuronal cell damage in culture and $\mathrm{A} \beta(25-35)$ - induced memory deficit in vivo may explain the inhibitory action of $A$. cordata on the progression of AD. Further studies should determine the specific components in A. cordata that are responsible for preventing the cognitive deficits.

\section{Acknowledgment}

This work was supported by a grant (Code 20080401034050) from the BioGreen 21 Program, Rural Development Administration, Republic of Korea.

\section{References}

1 Price DL, Tanzi RE, Borchelt DR, Sisodia SS. Alzheimer's disease: Genetic studies and transgenic models. Annu Rev Genet. 1998;32:461-493.

2 Ivins KJ, Ivins JK, Sharp JP, Cotman CW. Multiple pathways of apoptosis in PC12 cells. Crma inhibits apoptosis induced by beta-amyloid. J Biol Chem. 1999;274:2107-2112.

3 Ekinci FJ, Linsley MD, Shea TB. Beta-amyloid-induced calcium influx induces apoptosis in culture by oxidative stress rather than tau phosphorylation. Brain Res Mol Brain Res. 2000;76:389395.

4 Gray CW, Patel AJ. Neurodegeneration mediated by glutamate and beta-amyloid peptide: A comparison and possible interaction. Brain Res. 1995;691:169-179.

5 Ueda K, Shinohara S, Yagami T, Asakura K, Kawasaki K. Amyloid beta protein potentiates $\mathrm{Ca}^{2+}$ influx through L-type voltage-sensitive $\mathrm{Ca}^{2+}$ channels: A possible involvement of free radicals. J Neurochem. 1997;68:265-271.

6 Van Dam D, De Deyn PP. Drug discovery in dementia: The role of rodent models. Nat Rev Drug Discov. 2006;5:956-970.

7 Nitta A, Fukuta T, Hasegawa T, Nabeshima T. Continuous infusion of beta-amyloid protein into the rat cerebral ventricle induces learning impairment and neuronal and morphological degeneration. Jpn J Pharmacol. 1997;73:51-57.

8 Butterfield DA, Lauderback CM. Lipid peroxidation and protein oxidation in Alzheimer's disease brain: Potential causes and consequences involving amyloid beta-peptide-associated free radical oxidative stress. Free Radic Biol Med. 2002;32:10501060 .

9 Butterfield DA, Reed T, Newman SF, Sultana R. Roles of amyloid beta-peptide-associated oxidative stress and brain protein modifications in the pathogenesis of Alzheimer's disease and mild cognitive impairment. Free Radic Biol Med. 2007; 43:658-677.

10 Gitter BD, Cox LM, Rydel RE, May PC. Amyloid beta peptide potentiates cytokine secretion by interleukin-1 beta-activated human astrocytoma cells. Proc Natl Acad Sci U S A. 1995;92: 10738-10741.

11 McDonald DR, Brunden KR, Landreth GE. Amyloid fibrils activate tyrosine kinase-dependent signaling and superoxide production in microglia. J Neurosci. 1997;17:2284-2294.

12 Yamada K, Tanaka T, Han D, Senzaki K, Kameyama T, Nabeshima T. Protective effects of idebenone and alphatocopherol on beta-amyloid-(1-42)-induced learning and memory deficits in rats: Implication of oxidative stress in beta-amyloidinduced neurotoxicity in vivo. Eur J Neurosci. 1999;11:83-90. 
13 Rogers J, Kirby LC, Hempelman SR, Berry DL, McGeer PL, Kaszniak AW, et al. Clinical trial of indomethacin in Alzheimer's disease. Neurology. 1993;43:1609-1611.

14 Sano M, Ernesto C, Thomas RG, Klauber MR, Schafer K, Grundman M, et al. A controlled trial of selegiline, alphatocopherol, or both as treatment for Alzheimer's disease. The Alzheimer's disease cooperative study. N Engl J Med. 1997; 336:1216-1222.

15 Pike CJ, Walencewicz-Wasserman AJ, Kosmoski J, Cribbs DH, Glabe CG, Cotman CW. Structure-activity analyses of betaamyloid peptides: Contributions of the beta 25-35 region to aggregation and neurotoxicity. J Neurochem. 1995;64:253-265.

16 Richardson JS, Zhou Y, Kumar U. Free radicals in the neurotoxic actions of beta-amyloid. Ann NY Acad Sci. 1996;777:362-367.

17 Perry LM. Medicinal plants of east and southeast Asia: Attributed properties and uses. Cambridge, MA: The MIT Press; 1980.

18 Okuyama E, Nishimura S, Yamazaki M. Analgesic principles from Aralia cordata thunb. Chem Pharm Bull. 1991;39:405-407.

19 Han BH, Han YN, Han LA, Park MH, Lee EO. Studies on the anti-inflammatory activity of Aralia contineltalis. Arch Pharm Res. 1983;6:17-23.

20 Dang NH, Zhang X, Zheng M, Son KH, Chang HW, Kim HP, et al. Inhibitory constituents against cyclooxygenases from Aralia cordata thunb. Arch Pharm Res. 2005;28:28-33.

21 Lee IS, Jin W, Zhang X, Hung TM, Song KS, Seong YH, et al. Cytotoxic and COX-2 inhibitory constituents from the aerial parts of Aralia cordata. Arch Pharm Res. 2006;29:548-555.

22 Hoehn BD, Palmer TD, Steinberg GK. Neurogenesis in rats after focal cerebral ischemia is enhanced by indomethacin. Stroke. 2005;36:2718-2724.

23 Pitchumoni SS, Doraiswamy PM. Current status of antioxidant therapy for Alzheimer's disease. J Am Geriatr Soc. 1998;46: $1566-1572$.

24 Ban JY, Jeon SY, Bae K, Song KS, Seong YH. Catechin and epicatechin from smilacis chinae rhizome protect cultured rat cortical neurons against amyloid beta protein (25-35)-induced neurotoxicity through inhibition of cytosolic calcium elevation. Life Sci. 2006;79:2251-2259.

25 Ban JY, Cho SO, Choi SH, Ju HS, Kim JY, Bae K, et al. Neuroprotective effect of Smilacis chinae rhizome on NMDA-induced neurotoxicity in vitro and focal cerebral ischemia in vivo. J Pharmacol Sci. 2008;106:68-77.

26 Maurice T, Lockhart BP, Privat A. Amnesia induced in mice by centrally administered beta-amyloid peptides involves cholinergic dysfunction. Brain Res. 1996;706:181-193.

27 Zhu MC, Xin YB, Sun MJ, Fang YZ. Purification and properties of acetylcholinesterase from human brain. Sci China B. 1993; 36:1207-1215.

28 Lee BY, Ban JY, Seong YH. Chronic stimulation of GABA receptor with muscimol reduces amyloid beta protein (25-35)induced neurotoxicity in cultured rat cortical cells. Neurosci Res. 2005;52:347-356.

29 Grace EA, Rabiner CA, Busciglio J. Characterization of neuronal dystrophy induced by fibrillar amyloid beta: Implications for Alzheimer's disease. Neuroscience. 2002;114:265-273.

30 Tohda C, Matsumoto N, Zou K, Meselhy MR, Komatsu K. A beta (25-35)-induced memory impairment, axonal atrophy, and synaptic loss are ameliorated by M1, a metabolite of protopanaxadiol-type saponins. Neuropsychopharmacology. 2004;29:
$860-868$.

31 Butterfield DA, Drake J, Pocernich C, Castegna A. Evidence of oxidative damage in Alzheimer's disease brain: Central role for amyloid beta-peptide. Trends Mol Med. 2001;7:548-554.

32 Mattson MP, Chan SL. Neuronal and glial calcium signaling in Alzheimer's disease. Cell Calcium. 2003;34:385-397.

33 Harkany T, Hortobagyi T, Sasvari M, Konya C, Penke B, Luiten $\mathrm{PG}$, et al. Neuroprotective approaches in experimental models of beta-amyloid neurotoxicity: Relevance to Alzheimer's disease. Prog Neuropsychopharmacol Biol Psychiatry. 1999;23:9631008.

34 Huang HM, Ou HC, Hsieh SJ. Antioxidants prevent amyloid peptide-induced apoptosis and alteration of calcium homeostasis in cultured cortical neurons. Life Sci. 2000;66:1879-1892.

35 Suh SJ, Jin UH, Kim KW, Son JK, Lee SH, Son KH, et al. Triterpenoid saponin, oleanolic acid 3-O-beta-d-glucopyranosyl $(1 \rightarrow 3)$-alpha-l-rhamnopyranosyl $(1 \rightarrow 2)$-alpha-l-ar abinopyranoside (oa) from Aralia elata inhibits LPS-induced nitric oxide production by down-regulated NF-kappaB in raw 264.7 cells. Arch Biochem Biophys. 2007;467:227-233.

36 Xi M, Hai C, Tang H, Chen M, Fang K, Liang X. Antioxidant and antiglycation properties of total saponins extracted from traditional chinese medicine used to treat diabetes mellitus. Phytother Res. 2008;22:228-237.

37 Tirapelli CR, Ambrosio SR, da Costa FB, de Oliveira AM. Evidence for the mechanisms underlying the effects of pimaradienoic acid isolated from the roots of Viguiera arenaria on rat aorta. Pharmacology. 2004;70:31-38.

38 Cherng JM, Lin HJ, Hung MS, Lin YR, Chan MH, Lin JC. Inhibition of nuclear factor kappab is associated with neuroprotective effects of glycyrrhizic acid on glutamate-induced excitotoxicity in primary neurons. Eur J Pharmacol. 2006;547: $10-21$.

39 Yan XZ, Qiao JT, Dou Y, Qiao ZD. Beta-amyloid peptide fragment 31-35 induces apoptosis in cultured cortical neurons. Neuroscience. 1999;92:177-184.

40 Chan PH. Reactive oxygen radicals in signaling and damage in the ischemic brain. J Cereb Blood Flow Metab. 2001;21:2-14.

41 Jang JH, Surh YJ. Beta-amyloid-induced apoptosis is associated with cyclooxygenase-2 up-regulation via the mitogen-activated protein kinase-NF-kappaB signaling pathway. Free Radic Biol Med. 2005;38:1604-1613.

42 Baek YH, Huh JE, Lee JD, Choi DY, Park DS. Effect of Aralia cordata extracts on cartilage protection and apoptosis inhibition. Biol Pharm Bull. 2006;29:1423-1430.

43 Um MY, Choi WH, Aan JY, Kim SR, Ha TY. Protective effect of polygonum multiflorum thunb on amyloid beta-peptide 25-35 induced cognitive deficits in mice. J Ethnopharmacol. 2006;104: 144-148.

44 Stepanichev MY, Moiseeva YV, Lazareva NA, Onufriev MV, Gulyaeva NV. Single intracerebroventricular administration of amyloid-beta (25-35) peptide induces impairment in short-term rather than long-term memory in rats. Brain Res Bull. 2003; 61:197-205.

45 Holscher C, Gengler S, Gault VA, Harriott P, Mallot HA. Soluble beta-amyloid[25-35] reversibly impairs hippocampal synaptic plasticity and spatial learning. Eur J Pharmacol. 2007; 561:85-90.

46 Huang HJ, Liang KC, Chen CP, Chen CM, Hsieh-Li HM. Intrahippocampal administration of a beta(1-40) impairs spatial 
learning and memory in hyperglycemic mice. Neurobiol Learn Mem. 2007;87:483-494.

47 Atack JR, Perry EK, Bonham JR, Perry RH, Tomlinson BE, Blessed G, et al. Molecular forms of acetylcholinesterase in senile dementia of Alzheimer type: Selective loss of the intermediate (10s) form. Neurosci Lett. 1983;40:199-204.

48 Morris R. Developments of a water-maze procedure for studying spatial learning in the rat. J Neurosci Methods. 1984;11:47-60.

49 Kontush A. Amyloid-beta: An antioxidant that becomes a prooxidant and critically contributes to Alzheimer's disease. Free Radic Biol Med. 2001;31:1120-1131.

50 Smith MA, Richey Harris PL, Sayre LM, Beckman JS, Perry G. Widespread peroxynitrite-mediated damage in Alzheimer's disease. J Neurosci. 1997; 17:2653-2657.

51 Alkam T, Nitta A, Mizoguchi H, Itoh A, Nabeshima T. A natural scavenger of peroxynitrites, rosmarinic acid, protects against impairment of memory induced by Abeta(25-35). Behav Brain Res. 2007;180:139-145.

52 Wenk GL. Neuropathologic changes in Alzheimer's disease: Potential targets for treatment. J Clin Psychiatry. 2006;67 Suppl 3:3-7; quiz 23.

53 Solntseva EI, Bukanova JV, Marchenko E, Skrebitsky VG. Donepezil is a strong antagonist of voltage-gated calcium and potassium channels in molluscan neurons. Comp Biochem Physiol C Toxicol Pharmacol. 2007;144:319-326.

54 Quartermain D, deSoria VG, Kwan A. Calcium channel antagonists enhance retention of passive avoidance and maze learning in mice. Neurobiol Learn Mem. 2001;75:77-90.

55 Quartermain D, Garcia deSoria V. The effects of calcium channel antagonists on short- and long-term retention in mice using spontaneous alternation behavior. Neurobiol Learn Mem. 2001;76:117-124.
56 Borroni AM, Fichtenholtz H, Woodside BL, Teyler TJ. Role of voltage-dependent calcium channel long-term potentiation (LTP) and NMDA LTP in spatial memory. J Neurosci. 2000;20:9272-9276.

57 Lashgari R, Motamedi F, Zahedi Asl S, Shahidi S, Komaki A. Behavioral and electrophysiological studies of chronic oral administration of L-type calcium channel blocker verapamil on learning and memory in rats. Behav Brain Res. 2006;171:324328.

58 Harooni HE, Naghdi N, Sepehri H, Rohani AH. The role of hippocampal nitric oxide (NO) on learning and immediate, short- and long-term memory retrieval in inhibitory avoidance task in male adult rats. Behav Brain Res. 2009;201:166-172.

59 Jafari-Sabet M. NMDA receptor blockers prevents the facilitatory effects of post-training intra-dorsal hippocampal NMDA and physostigmine on memory retention of passive avoidance learning in rats. Behav Brain Res. 2006;169:120-127.

60 Majlessi N, Choopani S, Bozorgmehr T, Azizi Z. Involvement of hippocampal nitric oxide in spatial learning in the rat. Neurobiol Learn Mem. 2008;90:413-419.

61 Milton AL, Lee JL, Butler VJ, Gardner R, Everitt BJ. Intraamygdala and systemic antagonism of NMDA receptors prevents the reconsolidation of drug-associated memory and impairs subsequently both novel and previously acquired drugseeking behaviors. J Neurosci. 2008;28:8230-8237.

62 Liu J. Pharmacology of oleanolic acid and ursolic acid. J Ethnopharmacol. 1995;49:57-68.

63 Du Y, Ko KM. Oleanolic acid protects against myocardial ischemia-reperfusion injury by enhancing mitochondrial antioxidant mechanism mediated by glutathione and alphatocopherol in rats. Planta Med. 2006;72:222-227. 